\title{
Biology and Management of Whiteflies in Sustainable Field Production of Cucurbits ${ }^{1}$
}

\section{O. E. Liburd and T.W. Nyoike ${ }^{2}$}

Whiteflies (Hemiptera: Aleyrodidae) are minute insects generally characterized by having wings covered with wax. Several species of whiteflies exist. They have a wide host range, including crops that are members of the Cucurbitaceae family (cucurbits). There are two whitefly biotypes that attack cucurbits in the field; the sweetpotato whitefly, Bemisia tabaci (Genn.) and the silverleaf whitefly, B biotype (also known as Bemisia argentifolii Bellows and Perring) (Figure 1).

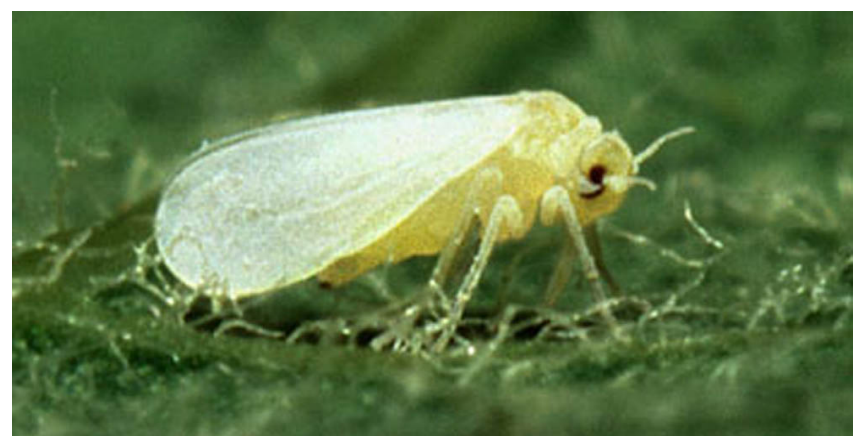

Figure 1. Adult Bemisia argentifolii Bellows \& Perring. Credits: Scott Bauer, USDA

\section{Biology and Lifecycle}

Whiteflies have six life stages: egg, four instars, and the adult. The eggs are usually elongate-oval in shape but occasionally may be reniform (bean shaped). The apex (distal end) of the egg is acute and the basal portion is usually broad, with a pedicel or stalk of varying length by which the female attaches to the host. Eggs are laid singly on the underside of the leaf and are white in color. Each female can produce up to 300 eggs (Nyoike 2007). The first instar, called the crawler, has legs and is the only mobile instar that moves to look for feeding sites. The other instars are sessile and they complete their lifecycle on the same leaf (McAuslane 2000). The life cycle is dependent on the temperature and plant species. It can take 14-60 days, but typically Bemisia spp. takes 20 days at $80^{\circ} \mathrm{F}$. These species reproduce parthenogenetically (reproduction without fertilization) (Zitter et al. 1996). In northern Florida, a high populations of Bemisia are often seen in the fall whereas in southern Florida populations tend to exist throughout the year with the peak in the summer.

1. This document is ENY-848 (IN762), one of a series of the Entomology \& Nematology Department, Florida Cooperative Extension Service, Institute of Food and Agricultural Sciences, University of Florida. First published: January 2008. For more publications related to horticulture/agriculture, please visit the EDIS Website at http://edis.ifas.ufl.edu/.

2. O. E. Liburd, associate professor and T. W. Nyoike, graduate assistant, Entomology and Nematology Department, Institute of Food and Agricultural Sciences, University of Florida, Gainesville, FL, 32611.

The Institute of Food and Agricultural Sciences (IFAS) is an Equal Opportunity Institution authorized to provide research, educational information and other services only to individuals and institutions that function with non-discrimination with respect to race, creed, color, religion, age, disability, sex, sexual orientation, marital status, national origin, political opinions or affiliations. U.S. Department of Agriculture, Cooperative Extension Service, University of Florida, IFAS, Florida A. \& M. University Cooperative Extension Program, and Boards of County Commissioners Cooperating. Larry Arrington, Dean 


\section{Damage}

Whiteflies damage cucurbits through direct feeding when they suck sap from the phloem, and excrete honeydew, a sugar-rich substrate that promotes the growth of sooty mold (Capnodium spp.), on harvestable plant parts and leaves. They also damage the plant by transmitting viruses, and induce physiological disorders (Figure 2). The B biotype transmits geminiviruses to cucurbits in a persistent manner (i.e., once the virus is acquired by the whitefly they retain the ability to transmit it for a long period). Squash silver leaf disorder (SSL) is a systemic physiological plant disorder associated with the feeding of immature whiteflies (B biotype of $B$. tabaci) (Figure 3) and is characterized by silvering of the upper leaf surface. Depending on the severity of squash silverleaf disorder, they can reduce the quality of the fruit produced, rendering it unmarketable.

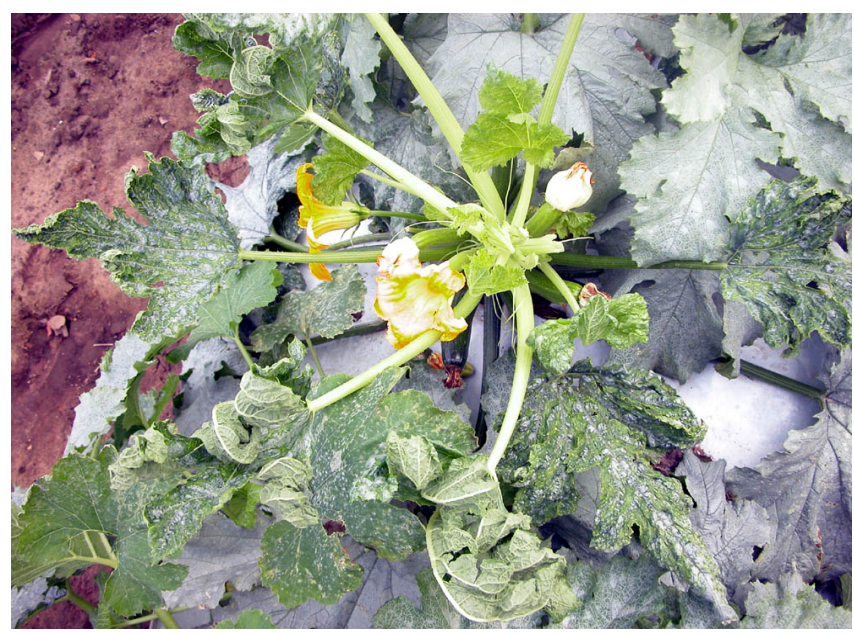

Figure 2. Cucurbit leaf crumple virus in zucchini squash. Credits: Teresia Nyoike, University of Florida

\section{Monitoring}

Monitoring is an essential part of a whitefly management program. Yellow sticky traps can be used to monitor adult whiteflies moving into the field. These traps also indicate when other sampling methods can be used. Yellow sticky traps have been reported to give a good correlation between catches and actual whitefly numbers in the field in some systems (Basu 1995) and hence their use is very popular in whitefly IPM programs. In-situ count (leaf turn method) is another sampling technique used to estimate the absolute population of adults in the field. These counts should be done in the morning when the

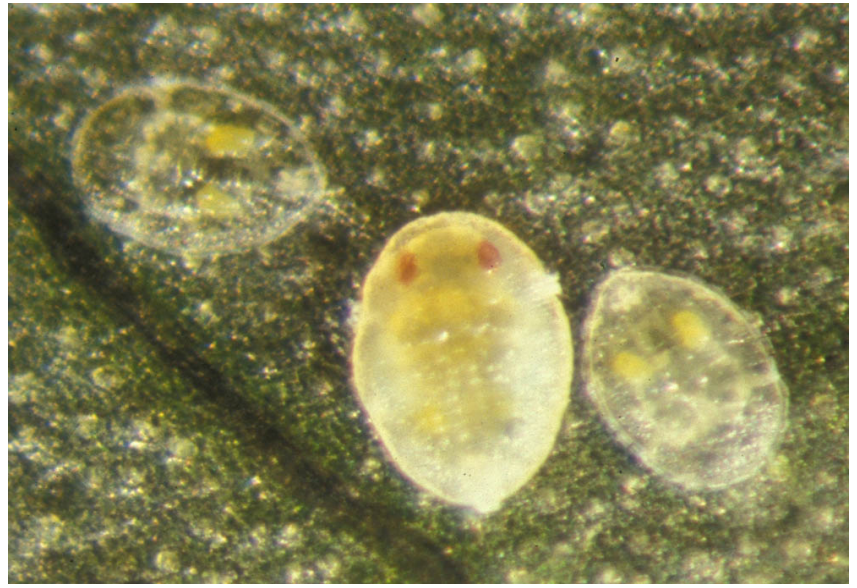

Figure 3. Bemisa tabaci (Gennadius) immature stage on the underside of leaf. Credits: J. Castner, University of Florida

whiteflies are least mobile. Quantification of immature whiteflies involves cutting of leaf discs of a designated area from the leaves to be sampled. The leaf discs are then examined under a microscope for identification of nymphal stages (Nyoike 2007). The eggs are laid on the younger leaves and the developing stages are found on the middle and older leaves.

\section{Management}

Prevention. In sustainable agriculture, prevention practices are the first line of defense for the growers. Such options include cultural techniques, use of physical barriers, removal of the crop in space and time, and the use of biological control agents. Some of the cultural practices available include mulching, crop rotation, floating row covers, and cover crops. Soil ground covers (synthetic and living mulches) have been shown to be effective in reducing whiteflies reaching host plants, and hence resulting in a lower incidence of whitefly-transmitted viruses (Frank and Liburd 2005, Nyoike 2007). UV-reflective mulch reflects short-wave light which repels incoming whiteflies, thus reducing their probability of alighting (landing) on host plants. Alternatively, living mulches decrease the chance of appropriate landings on host plants by reducing the contrast between bareground and the plant canopy, hence diminishing the activities of whiteflies on its host. In addition, whiteflies are less likely to remain in mixed croppings, which have fewer resources as compared to pure stands (without 
living mulches). Living mulches also provide habitats for natural enemies (beneficial insects) that can contribute to pest reduction.

Seasonal maintence. Some biological control agents including Encarsia formosa, Encarsia luteola and Eretmocerus californicus have been fairly successful in the greenhouse. There are very few cases of successes that have been reported under field conditions. However, horticultural oils and insecticidal soaps such as (M-Pede) can be used to reduce field populations. A few biological pesticides, including Beauveria bassiana (Naturalis- $\mathrm{O}^{\circledR}$ and BotaniGard $\left.^{\circledR}\right)$, Paecilomyces fumosoroseus (PFR-97®), and a few neem-based formulations containing azadirachtin (Neemazad \& Azatin) have been reported to affect whitefly developmental stages.

\section{Summary}

Whiteflies can be a major problem in the production of cucurbits. Growers who have whiteflies and viral symptoms should contact their County Extension Agents or submit samples to Plant Clinic Diagnostic Laboratory (PCDL) at the University of Florida for identification. Samples can also be submitted electronically through Distance Diagnostic and Identification System (DDIS). Information on submitting samples through this system can be found at http://ddis.ifas.ufl.edu/.

\section{References}

Basu, A. N., 1995. Bemisia tabaci (Gennadius) crop pest and principal whitefly vector of plant viruses. Westview Press, USA.

Frank, D. L., and O. E. Liburd. 2005. Effects of living and synthetic mulch on the population dynamics of whiteflies and aphids, their associated natural enemies and insect-transmitted plant diseases in zucchini. Environ Entomol. 34: 857-865.

McAuslane, H. J., 2000. Sweetpotato whitefly B Biotype of silverleaf whitefly, Bemisia tabaci (Gennadius) or Bemisia argentifolii Bellows and Perring (Insecta: Homoptera: Aleyrodidae). University of Florida, IFAS Extension EENY129.
Nyoike, T. W. 2007. Evaluation of living and synthetic mulches with and without a reduced-risk insecticide for suppression of whiteflies and aphids, and insect transmitted viral diseases in zucchini squash. A thesis submitted to the Graduate school, University of Florida, Gainesville. 90 pp. in partial fulfillment for MS in integrated pest management.

Zitter, A. T., D. L. Hopkins, and C. E. Thomas, 1996. Compendium of cucurbit diseases. APS Press, St Paul, Minnesota, USA Pp. 80. 